\title{
POŠTA
}

TELEKOMUNIKÁCIE A

ELEKTRONICKY OBCHOD

\section{PRIESKUM KVALITY POSKYTOVANÝCH SLUŽIEB POŠTOVEJ BANKY, A. S. NA POŠTE KEŽMAROK 1}

\author{
Martina Gogolová ${ }^{1}$, Eva Kovalčíková ${ }^{2}$
}

\section{1. ÚVOD}

Kvalita je v súčasnosti najvýznamnejším aspektom podnikatel'ského úspechu a spolu s cenou je zároveň hlavným faktorom vol'by zákazníka v otázke služieb. Budúcnost' každej organizácie poskytujúcej služby je bytostne závislá na správaní sa jednotlivých skupín zákazníkov. Pre dosiahnutie maximálnej spokojnosti a lojality zákazníkov je potrebné systematické preskúmanie požiadaviek zákazníkov, ich rýchle a efektívne uspokojovanie a systematické meranie ich spokojnosti a lojality. Zámerom príspevku je poukázat' na prípadné nedostatky v oblasti poskytovania služieb na Pošte Kežmarok 1 a navrhnút' opatrenia, ktoré by viedli k zvýšeniu kvality a tým aj spokojnosti zákazníkov.

\section{PRIESKUM KVALITY POSKYTOVANÝCH SLUŽIEB}

\subsection{Metodika}

Ciel'om prieskumu bolo zistit', ako vnímajú zákazníci Poštovej banky, a.s. kvalitu služieb na Pošte Kežmarok 1, porovnat' ju s kvalitou služieb poskytovaných na Pošte Kežmarok 3 a navrhnút' opatrenia na odstránenie zistených nedostatkov.

Boli stanovené nasledujúce hypotézy, ktoré prieskum svojimi výsledkami potvrdil alebo vyvrátil:

- viac ako 50\% oslovených zákazníkov je s kvalitou služieb úplne spokojných,

- $80 \%$ zákazníkov považuje odbornú znalost' zamestnancov za vel'mi dôležité kritérium,

- $80 \%$ zákazníkov považuje ochotu a správanie sa zamestnancov za vel'mi dôležité kritérium,

- $\quad$ viac ako $70 \%$ zákazníkov sú s dobou čakania na obsluhu úplne spokojní.

Na prieskum kvality poskytovaných služieb Poštovej banky, a.s. na Pošte Kežmarok 1 bolo zvolené osobné dopytovanie. Dopytovanie prebehlo anonymne pri priehradke Pošty Kežmarok 1 a Kežmarok 3.

\footnotetext{
${ }^{1}$ Ing. Martina Gogolová, PhD., Katedra ekonomiky, F PEDAS, ŽU v Žiline, Univerzitná 1, 01026 Žilina, Slovenská republika, e-mail: martina.gogolova@fpedas.uniza.sk

${ }^{2}$ Ing. Eva Kovalčíková, Pošta Kežmarok 1, Mučeníkov 2, 06001 Kežmarok
} 
Dostupnú vzorku pri prieskume kvality poskytovaných služieb Poštovej banky, a.s. na Pošte Kežmarok 1 a na pošte Kežmarok 3 tvorili zákazníci vo veku nad 18 rokov. Výberový súbor tvorilo spolu 200 respondentov.

$\mathrm{Na}$ získavanie primárnych údajov pri prieskume bol použitý dotazník ako jeden $\mathrm{z}$ nástrojov marketingového prieskumu. Dotazník vypĺn̆ali respondenti priamo v mieste spotreby pri priehradke na Pošte 1 a na Pošte 3.

Dotazník obsahoval celkom 15 uzatvorených otázok, ktoré boli formulované tak, aby ich vypíňanie bolo pre respondentov čo najjednoduchšie a časovo čo najmenej náročné. V dotazníku boli zist'ované nasledujúce informácie:

- celková spokojnost' so službami Poštovej banky, a.s., pričom bola použitá stupnica od $3-0$, kde 3 predstavovala úplnú spokojnost' a 0 predstavovala úplnú nespokojnost',

- spokojnost's jednotlivými kritériami kvality služieb, pričom bola použitá stupnica od 3 -0, kde 3 predstavovala úplnú spokojnost' a 0 predstavovala úplnú nespokojnost',

- dôležitost' jednotlivých kritérií kvality, pričom bola použitá stupnica od 3 - 0 , kde 3 predstavovala najvyššiu dôležitost' daného kritéria a 0 predstavovala nedôležitost' daného kritéria kvality,

- v časti týkajúcej sa respondenta bola zist'ovaná veková kategória, sociálne postavenie a ako často respondenti navštevujú Poštovú banku, a.s. na pošte.

Výsledky prieskumu boli štatisticky spracované a graficky prezentované. Použili sa nasledujúce štatistické ukazovatele: absolútna početnost', relatívna početnost', kumulovaná početnost', aritmetický priemer, medián, modus, rozptyl, štandardná odchýlka a variačný koeficient.

\subsection{Výsledky prieskumu}

Prieskum kvality poskytovaných služieb Poštovej banky, a.s. bol zrealizovaný v mesiacoch jún - júl 2008 priamo v mieste spotreby (priehradka Pošty Kežmarok 1 a Pošty Kežmarok 3) a to počas úradných hodín. Počas prieskumu bolo oslovených spolu 200 zákazníkov Poštovej banky nad 18 rokov. Pri prieskume bol použitý dotazník. Návratnost' správne a úplne vyplnených dotazníkov bola $100 \%$. Výsledky boli percentuálne spracované do tabuliek, pomocou štatistických veličín vyhodnotené, slovne a graficky interpretované podl'a jednotlivých otázok z dotazníka.

\section{Celková spokojnost' s poskytovaním služieb Poštovej banky, a.s.}

Na základe výsledkov prieskumu sa dospelo k nasledujúcim skutočnostiam: na Pošte Kežmarok 1 je so službami Poštovej banky, a.s. úplne spokojných a spokojných spolu 93\% zákazníkov a 6\% zákazníkov je menej spokojných. Na Pošte Kežmarok 3 je so službami Poštovej banky, a.s. úplne spokojných a spokojných spolu 75\% zákazníkov, 17\% zákazníkov je menej spokojných a $8 \%$ je nespokojných (vid'. obr. 1). 


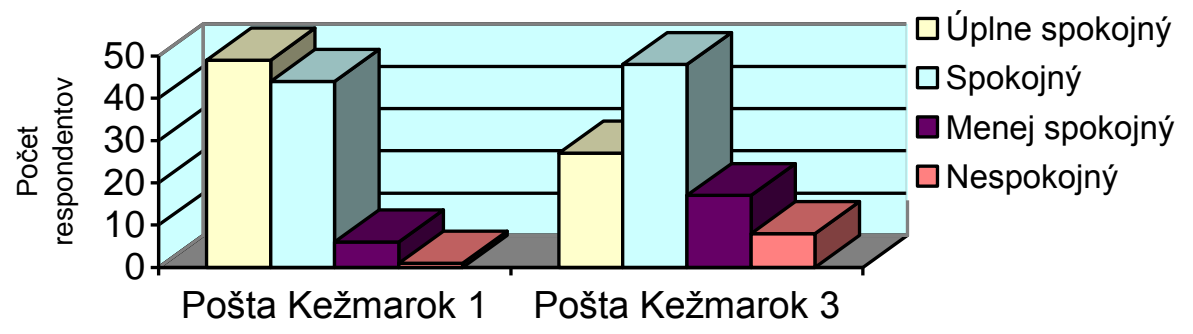

Obr. 1 Hodnotenie celkovej spokojnosti s poskytovaním služieb Poštovej banky Zhodnotenie kvality služieb Poštovej banky, a.s. na Pošte Kežmarok 1 v porovnaní s konkurenciou.

Z prieskumu spokojnosti s kritériami kvality služieb Poštovej banky, a.s. na Pošte Kežmarok 1 a Kežmarok 3 vyplýva, že zákazníci na Pošte Kežmarok 1 prejavili vyššiu spokojnost' s poskytovaním služieb Poštovej banky, a.s. ako na Pošte Kežmarok 3. Respondenti na Pošte Kežmarok 1 ohodnotili spokojnost' so všetkými kritériami kvality vyšším bodovým hodnotením ako respondenti na Pošte Kežmarok 3 (vid'. tab. 1). Medzi kritériá, s ktorými sú zákazníci na Pošte Kežmarok 1 najviac spokojní patrí: odborná znalost' zamestnancov, vystupovanie zamestnancov a propagácia produktov. 
Tabul'ka 1 Prehl'ad hodnotenia spokojnosti

\begin{tabular}{|c|c|c|c|c|c|c|c|c|}
\hline Spokojnost' & Pošta & $\mathrm{N}$ & Priemer & Medián & Modus & Rozptyl & $\begin{array}{l}\text { Štandardná } \\
\text { odchýlka }\end{array}$ & $\begin{array}{l}\text { Variačný } \\
\text { koeficient }\end{array}$ \\
\hline \multirow{2}{*}{ Celková spokojnost' } & KK 1 & 100 & 2,41 & 2 & 3 & 0,422 & 0,649 & 0,269 \\
\hline & KK 3 & 100 & 1,94 & 2 & 2 & 0,756 & 0,869 & 0,448 \\
\hline \multirow{2}{*}{ Odborná znalost' } & KK 1 & 100 & 2,64 & 3 & 3 & 0,29 & 0,538 & 0,204 \\
\hline & KK 3 & 100 & 2,17 & 2 & 2 & 0,401 & 0,633 & 0,292 \\
\hline \multirow{2}{*}{$\begin{array}{l}\text { Vystupovanie } \\
\text { zamestnancov }\end{array}$} & KK 1 & 100 & 2,61 & 3 & 3 & 0,318 & 0,564 & 0,216 \\
\hline & KK 3 & 100 & 2,37 & 2 & 3 & 0,433 & 0,658 & 0,278 \\
\hline \multirow{2}{*}{ Riešenie st'ažností } & KK 1 & 100 & 2,13 & 2 & 2 & 0,578 & 0,76 & 0,357 \\
\hline & KK 3 & 100 & 1,93 & 2 & 2 & 0,585 & 0,765 & 0,396 \\
\hline \multirow{2}{*}{$\begin{array}{l}\text { Doba čakania na } \\
\text { obsluhu }\end{array}$} & KK 1 & 100 & 2,15 & 2 & 3 & 0,807 & 0,899 & 0,418 \\
\hline & KK 3 & 100 & 1,61 & 2 & 2 & 0,698 & 0,835 & 0,519 \\
\hline \multirow{2}{*}{$\begin{array}{l}\text { Rýchlost' obsluhy pri } \\
\text { priehradke }\end{array}$} & KK 1 & 100 & 2,33 & 3 & 3 & 0,681 & 0,825 & 0,354 \\
\hline & KK 3 & 100 & 1,71 & 2 & 2 & 0,666 & 0,816 & 0,477 \\
\hline \multirow{2}{*}{$\begin{array}{l}\text { Umiestnenie propag. } \\
\text { materiálov }\end{array}$} & KK 1 & 100 & 2,07 & 2 & 2 & 0,465 & 0,682 & 0,329 \\
\hline & KK 3 & 100 & 2,16 & 2 & 2 & 0,434 & 0,659 & 0,305 \\
\hline \multirow{2}{*}{$\begin{array}{l}\text { Propagácia } \\
\text { produktov }\end{array}$} & KK 1 & 100 & 2,27 & 2 & 2 & 0,357 & 0,598 & 0,263 \\
\hline & KK 3 & 100 & 2,24 & 2 & 2 & 0,422 & 0,65 & 0,29 \\
\hline
\end{tabular}

\section{Vlastné spracovanie}

Z prieskumu dôležitosti jednotlivých kritérií kvality služby Poštovej banky, a.s. na Pošte Kežmarok 1 a Kežmarok 3 vyplýva, že pre zákazníkov na Pošte Kežmarok 1 sú jednotlivé kritériá kvality dôležitejšie ako pre zákazníkov na Pošte Kežmarok 3 (vid’. obr. 2). Medzi najdôležitejšie kritériá kvality pre zákazníkov na Pošte Kežmarok 1 patrí: odborná znalost' zamestnancov, vystupovanie zamestnancov, rýchlost' obsluhy pri priehradke a doba čakania na obsluhu. 
Tabul'ka 2 Prehl'ad hodnotenia dôležitosti

\begin{tabular}{|c|c|c|c|c|c|c|c|c|}
\hline Dôležitost' & Pošta & $\mathrm{N}$ & Priemer & Medián & Modus & Rozptyl & $\begin{array}{l}\text { Štandardná } \\
\text { odchýlka }\end{array}$ & $\begin{array}{l}\text { Variačný } \\
\text { koeficient }\end{array}$ \\
\hline \multirow{2}{*}{ Odborná znalost' } & KK 1 & 100 & 2,83 & 3 & 3 & 0,141 & 0,376 & 0,133 \\
\hline & KK 3 & 100 & 2,73 & 3 & 3 & 0,277 & 0,526 & 0,193 \\
\hline \multirow{2}{*}{$\begin{array}{l}\text { Vystupovanie } \\
\text { zamestnancov }\end{array}$} & KK 1 & 100 & 2,86 & 3 & 3 & 0,16 & 0,4 & 0,14 \\
\hline & KK 3 & 100 & 2,67 & 3 & 3 & 0,341 & 0,584 & 0,219 \\
\hline \multirow{2}{*}{ Riešenie st'ažností } & KK 1 & 100 & 2,54 & 3 & 3 & 0,428 & 0,654 & 0,257 \\
\hline & KK 3 & 100 & 2,46 & 3 & 3 & 0,588 & 0,767 & 0,312 \\
\hline \multirow{2}{*}{$\begin{array}{l}\text { Doba čakania na } \\
\text { obsluhu }\end{array}$} & KK 1 & 100 & 2,79 & 3 & 3 & 0,186 & 0,431 & 0,154 \\
\hline & KK 3 & 100 & 2,52 & 3 & 3 & 0,37 & 0,608 & 0,241 \\
\hline \multirow{2}{*}{$\begin{array}{l}\text { Rýchlost' obsluhy } \\
\text { pri priehradke }\end{array}$} & KK 1 & 100 & 2,72 & 3 & 3 & 0,242 & 0,491 & 0,18 \\
\hline & KK 3 & 100 & 2,51 & 3 & 3 & 0,51 & 0,714 & 0,284 \\
\hline \multirow{2}{*}{$\begin{array}{l}\text { Umiestnenie propag. } \\
\text { Materiálov }\end{array}$} & KK 1 & 100 & 2,14 & 2 & 2 & 0,46 & 0,678 & 0,317 \\
\hline & KK 3 & 100 & 1,64 & 2 & 2 & 1,15 & 1,07 & 0,652 \\
\hline \multirow{2}{*}{$\begin{array}{l}\text { Propagácia } \\
\text { produktov }\end{array}$} & KK 1 & 100 & 2,32 & 2 & 2 & 0,338 & 0,581 & 0,25 \\
\hline & KK 3 & 100 & 2,29 & 2 & 2 & 0,727 & 0,853 & 0,372 \\
\hline
\end{tabular}

Vlastné spracovanie

\section{Potvrdenie, respektíve vyvrátenie stanovených hypotéz}

Hypotézu, že viac ako 50\% zákazníkov je s kvalitou služieb úplne spokojných, prieskum potvrdil. Na základe odpovedí uvedených $\mathrm{v}$ dotazníku bolo zistené, že s celkovou spokojnost’ou so službami Poštovej banky, a.s. je až 93\% zákazníkov spokojných, z toho 49\% je úplne spokojných.

Hypotézu, že $80 \%$ zákazníkov považuje odbornú znalost' zamestnancov za vel’mi dôležité kritérium, prieskum potvrdil. Z prieskumu vyplýva, že $83 \%$ zákazníkov považuje odbornú znalost' za vel'mi dôležité kritérium.

Hypotézu, že $80 \%$ zákazníkov považuje ochotu a správanie sa zamestnancov za vel'mi dôležité, prieskum opät' potvrdil. Pre $88 \%$ zákazníkov je správanie sa zamestnancov vel'mi dôležité kritérium.

Hypotézu, že viac ako 50\% zákazníkov je s dobou čakania na obsluhu úplne spokojných, prieskum vyvrátil. Z prieskumu vyplýva, že s dobou čakania na obsluhu je úplne spokojných len $44 \%$ oslovených zákazníkov. 


\section{ZÁVER}

I napriek vysokej spokojnosti klientov Poštovej banky, a.s. na Pošte Kežmarok 1 je potrebné venovat' trvalú pozornost' kvalite poskytovaných služieb. Kvalitu služby je najdôležitejšie hodnotit' najmä z pohl'adu zákazníkov. Požiadavky zákazníkov sa stávajú čoraz náročnejšími. To, čo bolo mimoriadne pred niekol'kými rokmi, sa v súčasnosti stáva bežným. Vysoký stupeň konkurencie zvyšuje potrebu nielen vysokej kvality, ale aj profesionálneho prístupu k zákazníkom. Je preto dôležité zamerat' sa na l'udský faktor a budovat' dobré a dlhodobé vzt'ahy medzi kontaktným personálom a zákazníkmi. Podniky poskytujúce služby musia venovat' osobitnú pozornost' zamestnancom, ktorí sa na poskytovaní služieb podiel'ajú. Vzt'ah podniku ku zamestnancom sa odráža v ich vzt'ahu k zákazníkom. Zamestnanci, ktorí sú v priamom kontakte so zákazníkmi rozhodujú o kvalite poskytnutej služby, o spokojnosti zákazníkov a v konečnom dôsledku aj o úspechu podniku. Z toho dôvodu sú na nich kladené vysoké nároky. Ide hlavne o ich prejav profesionálnosti poskytnút' požadovanú službu, o spôsob komunikácie so zákazníkmi, vonkajší prejav ich nálady, schopnost' prezentovat' aj širšiu ponuku služieb podniku, vyzdvihnút' jedinečné vlastnosti služby a zdôrazňovat' image podniku. V očiach zákazníkov stelesňujú podnik, ktorý zákazníci navštívili. Zvlášt' významné je budovanie dôvery najmä vo finančných službách, kde zákazník splnomocňuje pracovníka na určité činnosti. Pracovník musí citlivo a pozorne udržiavat' úroveň dôvery zákazníka, musí vyžarovat' istotu, sebadôveru a zdvorilost'. Preto jednou $\mathrm{z}$ primárnych požiadaviek podnikov pôsobiacich $\mathrm{V}$ terciárnom sektore je zamestnávanie kvalitného a odborne zdatného personálu, ktorý sa stal významným zdrojom konkurenčnej výhody.

\section{Literatúra}

[1] KOVALČÍKOVÁ , E.: Kvalita poskytovaných služieb Poštovej banky, a.s. na Pošte Kežmarok 1. Diplomová práca. Žilinská univerzita v Žiline, F PEDAS, Katedra ekonomiky, Žilina, 2009

\section{Grantová podpora}

VEGA č. 1/0471/08 Marketingová komunikácia podniku služieb - integrovaný model podnikovej komunikácie a komunikácie so zákazníkom. 